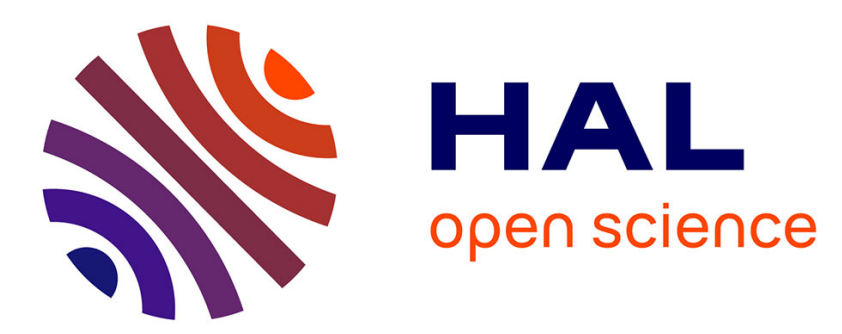

\title{
A new dragonfly family from the mid Cretaceous Burmese amber (Odonata: Aeshnoptera: Burmaeshnidae)
}

Diying Huang, Chenyang Cai, André Nel, Günter Bechly

\section{To cite this version:}

Diying Huang, Chenyang Cai, André Nel, Günter Bechly. A new dragonfly family from the mid Cretaceous Burmese amber (Odonata: Aeshnoptera: Burmaeshnidae). Cretaceous Research, 2017, 10.1016/j.cretres.2017.05.025 . hal-01528788

\section{HAL Id: hal-01528788 \\ https://hal.sorbonne-universite.fr/hal-01528788}

Submitted on 29 May 2017

HAL is a multi-disciplinary open access archive for the deposit and dissemination of scientific research documents, whether they are published or not. The documents may come from teaching and research institutions in France or abroad, or from public or private research centers.
L'archive ouverte pluridisciplinaire HAL, est destinée au dépôt et à la diffusion de documents scientifiques de niveau recherche, publiés ou non, émanant des établissements d'enseignement et de recherche français ou étrangers, des laboratoires publics ou privés. 
A new dragonfly family from the mid Cretaceous Burmese amber

(Odonata: Aeshnoptera: Burmaeshnidae)

Diying Huang ${ }^{\mathrm{a}^{*}}$, Chenyang Cai ${ }^{\mathrm{a}},{\text { André } \mathrm{Nel}^{\mathrm{b}^{*}}, \text { Günter Bechly }}^{\mathrm{c}}$

${ }^{a}$ State Key Laboratory of Palaeobiology and Stratigraphy, Nanjing Institute of Geology and Palaeontology, Chinese Academy of Sciences, Nanjing 210008, People's Republic of China (dyhuang@nigpas.ac.cn)

${ }^{b}$ Institut de Systématique, Évolution, Biodiversité, ISYEB - UMR 7205 - CNRS, MNHN, UPMC, EPHE, Muséum national d'Histoire naturelle, Sorbonne Universités, 57 rue Cuvier, CP 50, Entomologie F-75005, Paris, France (anel@mnhn.fr)

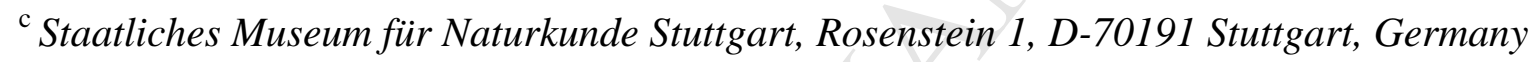
(guenter.bechly@smns-bw.de)

* Corresponding authors:

E-mail addresses: dyhuang@nigpas.ac.cn (D.-y. Huang); anel@mnhn.fr (A. Nel)

\begin{abstract}
The third Cretaceous Aeshnoptera in amber is described from Myanmar. It represents a new family Burmaeshnidae fam. nov., genus and species Burmaeshna azari gen. et sp. nov. Its exact affinities remain uncertain but it is probably the sister group of the Late Cretaceous family Enigmaeshnidae. This discovery supports the hypothesis of an intense period of appearance of many aeshnopteran subclades during the late Early Cretaceous and the Late Cretaceous.
\end{abstract}


Keywords:

Aeshnoptera

Diversity

gen. et sp. nov.

earliest Cenomanian

Myanmar

\section{Introduction}

Aeshnoptera are very diverse in the Jurassic and Cretaceous fossil record, but they almost all belong to the most inclusive clades of this group (Nel et al. 1994; Bechly et al. 2001). Mesozoic representatives of the Recent clade Neoaeshnida Bechly, 1996 are almost exclusively represented by the Gomphaeschnidae Tillyard and Fraser, 1940, sister group of the modern Aeshnodea Bechly, 1996. The few Mesozoic fossils of the latter clade belong to the family Allopetaliidae Cockerell, 1913. It seems that the Aeshnoptera had a period of intense diversification into several subclades during the Late Cretaceous (Nel et al., 2008). Here we describe the third Cretaceous aeshnopteran fossilized in amber, representing a further new family. The first one was a gomphaeschnid and the second a telephlebiid (Zheng et al., 2016, 2017).

\section{Materials and methods}

Fossils were examined and measured using an incident light stereomicroscope (Olympus SZX9) and a stereomicroscope (Nikon SMZ 1500), as well as a Leitz Wetzlar binocular microscope. Photographs were taken using a Zeiss Discovery V20 microscope system. Optical instruments were equipped with camera lucida and digital cameras. The raw 
digital images were processed with focus stacking software, and figure plates prepared with Adobe Photoshop ${ }^{\mathrm{TM}}$.

The nomenclature of the odonatan wing venation used in this paper is based on the interpretations of Riek \& Kukalová-Peck (1984), as modified by Nel et al. (1993) and Bechly (1996). The higher classification of fossil and extant Odonatoptera, as well as family and generic characters followed in the present work, are based on the phylogenetic system proposed by Bechly (1996) for the phylogeny of the extant Anisoptera. Wing abbreviations are as follows: $\mathrm{CuA}$, cubitus anterior; IR1, intercalary radial veins; MA, median anterior; MP, median posterior; N, nodus; Pt, pterostigma; RA, radius anterior; RP, radius posterior; $\mathrm{Sn}$, subnodal crossvein. All measurements are given in $\mathrm{mm}$.

The specimen is preserved in a piece of relatively clear, yellow Birmite amber. The amber piece was polished before being examined and photographed. All amber material was legally acquired in Myanmar from local traders with government registration, and legally exported according to the official regulations in Myanmar.

Fossil-bearing amber has mostly been collected from the Hukawng Valley in northern Myanmar (formerly known as Burma). For an overview of the amber deposit and its geological setting see, e.g., Zherikhin and Ross (2000), Grimaldi et al. (2002), Cruickshank and Ko (2003), and Ross et al. (2010). Radiometric U-Pb zircon dating (Shi et al., 2012) recently constrained this amber to a minimum age of $98.79 \pm 0.62 \mathrm{Ma}$, which is equivalent to the mid-Cretaceous (earliest Cenomanian). The original habitat of the amber forest is still controversial, in fact it has originally been assumed to be a tropical araucarian forest (Grimaldi et al., 2002; Poinar et al., 2007), possibly with Dipterocarpaceae as another source for the fossil resin. However, the first detailed report on the macromolecular nature and palaeobotanical affinity of Birmite (Dutta et al., 2011), based on gas chromatography - mass spectrometry, rejected Araucariaceae and Dipterocarpaceae in favour of Pinaceae as the 
Burmese amber tree, but Tappert et al. (2013) proposed a cupressacean origin. Grimaldi (2016), after Grimaldi and Ross (in press), considered 'based on the abundant inclusions of leafy shoots' that it was formed by a conifer, and 'amber produced possibly by Metasequoia (Taxodiaceae) or a close relative'.

The family, genus, and species are registered in Zoobank under the urn: lsid:zoobank.org:pub:892D0715-472B-4FB8-BBEB-CD7DE628B545.

\section{Systematic palaeontology}

ODONATA Fabricius, 1793

ANISOPTERA Selys in Selys and Hagen, 1854

AESHNOPTERA Bechly, 1996

BURMAESHNIDAE fam. nov.

Type genus. Burmaeshna gen. nov.

Diagnosis. Wing venation only. Discoidal triangles very elongate; well-defined Mspl parallel to MA; two oblique veins "O" between RP2 and IR2; very elongate anal area with an anal loop distinctly longer than wide; presence of three primary antenodal crossveins $\mathrm{Ax} 1$, 'Ax2' and 'Ax3' in hindwing, with arculus situated between 'Ax2' and 'Ax3', while only two primary antenodals $\mathrm{Ax} 1$ and $\mathrm{Ax} 2$ in forewing.

Burmaeshna gen. nov.

Type species. Burmaeshna azari sp. nov.

Diagnosis. As for the family. Subdiscoidal spaces and hypertriangles free; reduced number of antenodal crossveins; two rows of cells in cubito-anal area of hind wing.

Burmaeshna azari sp. nov. 
(Figs 1-2)

Holotype. NIGP165259 (incomplete fore- and hindwing), deposited at the Nanjing institute of Geology and Palaeontology.

Locality and Horizon. Hukawng Valley, Kachin Province, Myanmar; lowermost Cenomanian, Upper Cretaceous.

Diagnosis. As for genus. Discoidal triangles divided into three smaller cells.

Description. Basal third of a forewing, hyaline, $20.6 \mathrm{~mm}$ long, width unknown due to wrapping of the wing; distance from base to arculus ca. $3.8 \mathrm{~mm}$; from arculus to base of RP3/4 $7.7 \mathrm{~mm}$; nodus not preserved; four antenodal crossveins of primary type, viz. with a triangular membrane between $\mathrm{C}, \mathrm{ScP}$ and radius, $\mathrm{Ax} 0$ at extreme base of wing; distance from wing base to Ax1 ca. 3.0 mm, between Ax1 and 'Ax2' $1.4 \mathrm{~mm}$, between 'Ax2' and 'Ax3' 1.7 $\mathrm{mm}$; seven to nine preserved secondary antenodals crossveins; arculus situated midway between 'Ax2' and 'Ax3'; anterior part of arculus curved, RP and MA separated in angle of arculus where posterior part of arculus touches anterior part; hypertriangle $4.4 \mathrm{~mm}$ long, free; discoidal triangle $0.8 \mathrm{~mm}$ distal of arculus, divided into three smaller cells, very elongate and rather narrow, with anterior side $3.4 \mathrm{~mm}$ long, and MAb $3.4 \mathrm{~mm}$ long, sigmoidal; postdiscoidal area with two rows of cells just after discoidal triangle and three more distally; a distinct convex trigonal planate, short and zigzagged; only basal part of a well-defined Mspl present, well-defined with one row of cells between it and MAa; base of Mspl four cells distal of discoidal triangle; basal part of area between RA and RP with four crossveins basal of RP3/4, and two distal of base of RP3/4 and basal of subnodus; area between RP and MA with three crossveins basal of $\mathrm{RP} 3 / 4$; $\mathrm{Bq}$ space very long, but only one $\mathrm{Bq}$ crossvein; median area free; submedian area crossed by curved CuP, situated below Ax1; subdiscoidal space free; one row of cells between MP and $\mathrm{CuA}$; two rows of cells in a narrow anal area; two rows of cells in area below $\mathrm{CuA}$; $\mathrm{CuA}$ without well-defined posterior branches. 
Basal half of a hind wing, hyaline, fragment $20.6 \mathrm{~mm}$ long, wing $7.7 \mathrm{~mm}$ wide; very briefly petiolated, with stem of anal vein $0.9 \mathrm{~mm}$ long; distance from base to arculus $6.6 \mathrm{~mm}$; from arculus to nodus $8.7 \mathrm{~mm}$; from arculus to base of RP3/4 $6.3 \mathrm{~mm}$; four antenodal crossveins of primary type, viz. with a triangular membrane between $\mathrm{C}, \mathrm{ScP}$ and radius, $\mathrm{Ax} 0$ at extreme base of wing, Ax1 3.6 mm distally, 'Ax2' 2.4 mm distally and a supplementary one 'Ax3' 1.7 $\mathrm{mm}$ distally, weaker than others and with a weaker membrane between C, ScP and RA; four secondary antenodal crossveins of first row not well aligned with the three crossveins of second row, distal of most distal primary antenodal; three postnodal crossveins preserved not well aligned with postsubnodal crossveins; one row of cells between RP1 and RP2; arculus $0.4 \mathrm{~mm}$ distal of Ax2; RP and MA separated in angle of arculus where posterior part of arculus touches curved anterior part; hypertriangle $3.9 \mathrm{~mm}$ long, free; discoidal triangle 0.7 mm distal of arculus, divided into three smaller cells, very elongate and rather narrow, with basal side $0.7 \mathrm{~mm}$ long, anterior side $2.9 \mathrm{~mm}$ long, and MAb $2.3 \mathrm{~mm}$ long, sigmoidal; postdiscoidal area with two rows of cells just after discoidal triangle, distally broadened with probably nine rows of cells along posterior wing margin; a distinct convex trigonal planate, short and zigzagged; only basal part of a well-defined Mspl present, well-defined with one row of cells between it and MAa; base of Mspl two cells distal of discoidal triangle; no pseudo-ScP distal of nodus; basal part of area between RA and RP with only one crossvein basal of RP3/4, and three distal of base of RP3/4 and basal of subnodus; area between RP and MA with one crossvein basal of RP3/4; two oblique veins "O”, one cell distal of base of RP2 and one cell distally; one row of cells between IR2 and RP3/4 at least till two cells distal of subnodus; base of RP2 aligned with subnodus; base of Rspl clearly visible, with one row of cells between it and IR2; one row of cells between MP and $\mathrm{CuAa}$; median area free; submedian area crossed by curved $\mathrm{CuP}$, situated between $\mathrm{Ax} 1$ and $\mathrm{Ax} 2$, closer to $\mathrm{Ax} 2$; subdiscoidal space free; no anal triangle and no anal angle (female specimen); postero-basal 
wing margin (AP) nearly straight; anal area very long but not very broad, $8.2 \mathrm{~mm}$ long, 3.4 mm wide, with two to three rows of very large cells between AA and AP basal of anal loop and no clear posterior branches of AA; anal loop two cells broad, much more elongate than broad, $3.4 \mathrm{~mm}$ long, $1.6 \mathrm{~mm}$ wide, hexagonal, posteriorly closed, divided into five cells; $\mathrm{CuAb}$ well-defined; cubito-anal area rather narrow, with three rows of cells between $\mathrm{CuAa}$ and posterior wing margin; CuAa with five posterior branches.

Discussion. Burmaeshna gen. nov. can be attributed to the Neoaeshnida Bechly, 1996 (Gomphaeschnidae + Aeshnodea) due to very elongate discoidal triangles, presence of only one row of cells between RP1 and RP2, well-defined Mspl and Rspl, parallel to MA and IR2, both pairs of wings with a strong convex secondary longitudinal vein (trigonal planate) in postdiscoidal area; in both pairs of wings MP and CuA closely parallel with only one row of cells between them up to wing margin (Bechly, 2016). Nevertheless, Burmaeshna has retained the two oblique veins "O" between RP2 and IR2, reduced for the Neoashnida. Burmaeshna shares with the Late Cretaceous family Enigmaeshnidae Nel et al., 2008 the very elongate anal area with an anal loop distinctly longer than wide (putative synapomorphies). The same character is possibly present in the Lower Cretaceous Anomalaeschna Bechly et al., 2001. Burmaeshna differs from Enigmaeshna Nel et al., 2008 in the free subdiscoidal space and hypertriangle, and the greatly reduced number of cells in all the areas and reduced number of antenodal crossveins (Nel et al., 2008). Burmaeshna differs from Anomalaeschna in the crossed discoidal triangle, and the position of the anal loop that is distal of the arculus level in Anomalaeschna. Therefore we consider that Burmaeshna represents a new family.

Burmaeshna has a unique character among the Aeshnoptera, viz. presence of three primary antenodal crossveins $\mathrm{Ax} 1$, 'Ax2' and 'Ax3', with arculus situated between 'Ax2' and 'Ax3', while in other Aeshnoptera, the arculus is situated between Ax1 and Ax2. Only Cymatophlebia purbeckensis Bechly et al., 2001 has three primary antenodals but its arculus 
is not between Ax2 and Ax3, but between Ax1 and Ax2 as in other Aeshnoptera (Bechly et al., 2001). Situations similar to what happen for Burmaeshna occur in some 'libelluloids' Synthemistidae (Fraser, 1952), in which a secondary antenodal crossvein between the true Ax1 and Ax2 has been reinforced to become identical to the true primary antenodals.

\section{Conclusions}

With the discovery of the Burmaeshnidae, there is no less than four aeshnopteran families currently recorded in the Late Cretaceous, two of them becoming extinct before the Paleocene, maybe during the K-T crisis or before. Extant Aeshnidae sensu stricto are still unknown before the early Paleogene, a period during which the Gomphaeschnidae are still the most diverse aeshnopteran family. No fossil odonatan is known in the Maastrichian.

\section{Acknowledgements}

Dr. Huang has been supported by the Strategic Priority Research Program (B) of Chinese Academy of Sciences (CAS) (XDB18000000), and the National Natural Science Foundation of China (41688103, 91514302).

\section{References}

1. Bechly, G., 1996. Morphologische Untersuchungen am Flügelgeäder der rezenten Libellen und deren Stammgruppenvertreter (Insecta; Pterygota; Odonata), unter besonderer Berücksichtigung der Phylogenetischen Systematik und des Grundplanes der Odonata. Petalura, Böblingen, Special Volume 2, 402 pp.

2. Bechly, G., 2016. Phylogenetic systematics of Odonata. - homepage on the Internet: https://dl.dropboxusercontent.com/u/13756162/Website/odonata/system.htm 
3. Bechly, G., Nel, A., Martínez-Delclòs, X., Jarzembowski, E.A., Coram, R., Martill, D., Fleck, G., Escuillié, F., Wisshak, M.M., Maisch, M., 2001. A revision and phylogenetic study of Mesozoic Aeshnoptera, with description of several new families, genera and species (Insecta: Odonata: Anisoptera). Neue Paläontologische Abhandlungen 4, 1-219.

4. Cockerell, T.D.A., 1913. Two fossil insects from Florissant with a discussion of the venation of the aeschnine dragon-flies. Proceedings of the United States National Museum 45, 577-583.

5. Cruickshank, R.D., Ko, K., 2003. Geology of an amber locality in the Hukaung Valley, northern Myanmar. Journal of Asian Earth Sciences 21, 441-455.

6. Dutta, S., Mallick, M., Kumar, K., Mann, U., Greewood, P.F., 2011. Terpenoid composition and botanical affinity of Cretaceous resins from India and Myanmar. International Journal of Coal Geology 85, 49-55.

7. Fabricius, J.C., 1793. Entomologia systematica emendata et aucta, secundum classes, ordines, genera, species, adjectis synonymis, locis, observationibus, descriptionibus. C.G. Proft, Hafniae [= Copenhagen], 3, 1-487 and 1-349.

8. Fraser, F.C., 1952. A further note on the remarkable characters of the Syntheminae (Corduliidae). Entomologists' Monthly Magazine 88, 158-159.

9. Grimaldi, D., 2016 Diverse orthorrhaphan flies (Insecta: Diptera: Brachycera) in amber from the Cretaceous of Myanmar: Brachycera in Cretaceous amber, Part VII. Bulletin of the American Museum of Natural History 408, 1-131.

10. Grimaldi, D., Engel, M.S., Nascimbene, P., 2002 Fossiliferous Cretaceous amber from Myanmar (Burma): its rediscovery, biotic diversity, and paleontological significance. American Museum Novitates 3361, 1-72. 
11. Grimaldi, D., Ross, A.S. (in press). Extraordinary Lagerstaetten in amber, with particular reference to the Cretaceous of Burma. In: Fraser, N.C., Sues, H.-D. (eds). Terrestrial Conservation Lagerstätten: Windows into the Evolution of Life on Land. Dunedin Press, Edinburgh, UK.

12. Nel, A., Martinez-Delclos, X., Paicheler, J.-C., Henrotay, M.n 1993. Les 'Anisozygoptera' fossiles. Phylogénie et classification (Odonata). Martinia Numéro Hors Série 3, 1-311.

13. Nel, A., Martínez-Delclòs, X., Escuillié, F., Brisac, P., 1994. Les Aeshnidae fossiles: Etat actuel des connaissances (Odonata, Anisoptera). Neues Jahrbuch für Geologie und Paläontologie, Abhandlungen 194, 143-186.

14. Nel, A., Néraudeau, D., Perrichot, V., Girard, V., Gomez, B. 2008. A new dragonfly family in the Upper Cretaceous of France (Insecta: Odonata: Aeshnoptera). Acta Palaeontologica Polonica 53, 165-168.

15. Poinar, G.O.Jr., Lambert, J.B., Wu, Y., 2007. Araucarian source of fossiliferous Burmese amber: spectroscopic and anatomical evidence. Journal of the Botanical Research Institute of Texas 1, 449-455.

16. Riek, E.F., Kukalová-Peck, J., 1984. A new interpretation of dragonfly wing venation based upon Early Carboniferous fossils from Argentina (Insecta: Odonatoidea) and basic characters states in pterygote wings. Canadian Journal of Zoology 62, 11501166.

17. Ross, A., Mellish, C., York, P., Crighton, B., 2010. Burmese amber. In: Penney, D. (Ed.), Biodiversity of fossils in amber from the major world deposits. Siri Scientific Press, Manchester, 208-235.

18. Selys-Longchamps, E. de, Hagen, H., 1954. Synopsis des Gomphines. Bulletin de l'Académie Royales des sciences et belles-lettres de Bruxelles 21, 23-114. 
19. Shi, G.-H., Grimaldi, D.A., Harlow, G.E., Wang, J., Yang, M.-C., Lei, W.-Y., Li, Q., Li, X.-H., 2012. Age constraints on Burmese amber based on U-Pb dating of zircons. Cretaceous Research 37, 155-163.

20. Tappert, R., McKellar, R.C., Wolfe, A.P., Tappert, M.C., Ortega-Blanco, J., Muehlenbachs, K., 2013. Stable carbon isotopes of C3 plant resins and ambers record changes in atmospheric oxygen since the Triassic. Geochimica et Cosmochimica Acta $121,240-262$.

21. Tillyard, R.J., Fraser, F.C., 1940. A reclassification of the order Odonata based on some new interpretations of the venation of the dragonfly wing. Part 3. The Australian Zoologist 9, 359-396.

22. Zheng, D.R., Jarzembowski, E.A., Chang, S.-C., Wang, B., 2016. A new true dragonfly (Odonata, Anisoptera, Gomphaeschnaoidini) from mid-Cretaceous Burmese amber. Proceedings of the Geologists' Association 127, 629-632.

23. Zheng, D.R., Chang, S.-C., Jarzembowski, E.A., Wang, B., 2017. The first aeshnoid dragonfly (Odonata: Anisoptera: Telephlebiidae) from mid-Cretaceous Burmese amber. Cretaceous Research 72, 109-109.

24. Zherikhin, V.V., Ross, A.J., 2000. A review of the history, geology and age of Burmese amber (Burmite). Bulletin of the Natural History Museum, Geological Series $56,3-10$.

Fig. 1. Burmaeshna azari gen. et sp. nov., holotype NIGP165259, hindwing, photographs. A, base from below; B, base from above; C, distal part from above; D, nodal region. Scale bars: $3 \mathrm{~mm}$. 
Fig. 2. Burmaeshna azari gen. et sp. nov., holotype NIGP165259. A-B, forewing, photographs. A, base; B, nodal region. Scale bars: $3 \mathrm{~mm}$; C, reconstruction of hindwing. Scale bar: $4 \mathrm{~mm}$.

A new dragonfly family from the mid Cretaceous Burmese amber

(Odonata: Aeshnoptera: Burmaeshnidae)

Diying Huang ${ }^{a^{*}}$, Chenyang Cai ${ }^{a}$, André Nel $^{b^{*}}$, Günter Bechly ${ }^{c}$

${ }^{a}$ State Key Laboratory of Palaeobiology and Stratigraphy, Nanjing Institute of Geology and Palaeontology, Chinese Academy of Sciences, Nanjing 210008, People's Republic of China (dyhuang@nigpas.ac.cn)

${ }^{b}$ Institut de Systématique, Évolution, Biodiversité, ISYEB - UMR $7205-C N R S, M N H N$, UPMC, EPHE, Muséum national d'Histoire naturelle, Sorbonne Universités, 57 rue Cuvier, CP 50, Entomologie F-75005, Paris, France (anel@mnhn.fr)

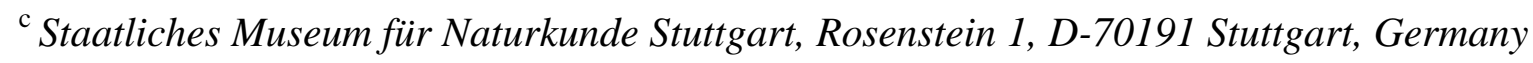
(guenter.bechly@smns-bw.de) 
* Corresponding authors:

E-mail addresses: dyhuang@nigpas.ac.cn (D.-y. Huang); anel@mnhn.fr (A. Nel)

\begin{abstract}
The third Cretaceous Aeshnoptera in amber is described from Myanmar. It represents a new family Burmaeshnidae fam. nov., genus and species Burmaeshna azari gen. et sp. nov. Its exact affinities remain uncertain but it is probably the sister group of the Late Cretaceous family Enigmaeshnidae. This discovery supports the hypothesis of an intense period of appearance of many aeshnopteran subclades during the late Early Cretaceous and the Late Cretaceous.
\end{abstract}

Keywords. Aeshnoptera; diversity; gen. et sp. nov.; Myanmar; earliest Cenomanian.

\title{
1. Introduction
}

Aeshnoptera are very diverse in the Jurassic and Cretaceous fossil record, but they almost all belong to the most inclusive clades of this group (Nel et al. 1994; Bechly et al. 2001). Mesozoic representatives of the Recent clade Neoaeshnida Bechly, 1996 are almost exclusively represented by the Gomphaeschnidae Tillyard and Fraser, 1940, sister group of the modern Aeshnodea Bechly, 1996. The few Mesozoic fossils of the latter clade belong to the family Allopetaliidae Cockerell, 1913. It seems that the Aeshnoptera had a period of intense diversification into several subclades during the Late Cretaceous (Nel et al., 2008). Here we describe the third Cretaceous aeshnopteran fossilized in amber, representing a further 
new family. The first one was a gomphaeschnid and the second a telephlebiid (Zheng et al., 2016, 2017).

\section{Materials and methods}

Fossils were examined and measured using an incident light stereomicroscope (Olympus SZX9) and a stereomicroscope (Nikon SMZ 1500), as well as a Leitz Wetzlar binocular microscope. Photographs were taken using a Zeiss Discovery V20 microscope system. Optical instruments were equipped with camera lucida and digital cameras. The raw digital images were processed with focus stacking software, and figure plates prepared with Adobe Photoshop ${ }^{\mathrm{TM}}$.

The nomenclature of the odonatan wing venation used in this paper is based on the interpretations of Riek \& Kukalová-Peck (1984), as modified by Nel et al. (1993) and Bechly (1996). The higher classification of fossil and extant Odonatoptera, as well as family and generic characters followed in the present work, are based on the phylogenetic system proposed by Bechly (1996) for the phylogeny of the extant Anisoptera. Wing abbreviations are as follows: $\mathrm{CuA}$, cubitus anterior; IR1, intercalary radial veins; MA, median anterior; MP, median posterior; N, nodus; Pt, pterostigma; RA, radius anterior; RP, radius posterior; $\mathrm{Sn}$, subnodal crossvein. All measurements are given in mm.

The specimen is preserved in a piece of relatively clear, yellow Birmite amber. The amber piece was polished before being examined and photographed. All amber material was legally acquired in Myanmar from local traders with government registration, and legally exported according to the official regulations in Myanmar.

Fossil-bearing amber has mostly been collected from the Hukawng Valley in northern Myanmar (formerly known as Burma). For an overview of the amber deposit and its geological setting see, e.g., Zherikhin and Ross (2000), Grimaldi et al. (2002), Cruickshank 
and Ko (2003), and Ross et al. (2010). Radiometric U-Pb zircon dating (Shi et al., 2012) recently constrained this amber to a minimum age of $98.79 \pm 0.62 \mathrm{Ma}$, which is equivalent to the mid-Cretaceous (earliest Cenomanian). The original habitat of the amber forest is still controversial, in fact it has originally been assumed to be a tropical araucarian forest (Grimaldi et al., 2002; Poinar et al., 2007), possibly with Dipterocarpaceae as another source for the fossil resin. However, the first detailed report on the macromolecular nature and palaeobotanical affinity of Birmite (Dutta et al., 2011), based on gas chromatography - mass spectrometry, rejected Araucariaceae and Dipterocarpaceae in favour of Pinaceae as the Burmese amber tree, but Tappert et al. (2013) proposed a cupressacean origin. Grimaldi (2016), after Grimaldi and Ross (in press), considered 'based on the abundant inclusions of leafy shoots' that it was formed by a conifer, and 'amber produced possibly by Metasequoia (Taxodiaceae) or a close relative'.

The family, genus, and species are registered in Zoobank under the urn: $x x x x$

\section{Systematic palaeontology}

Order: Odonata Fabricius, 1793

Suborder Anisoptera Selys in Selys and Hagen, 1854

Clade Aeshnoptera Bechly, 1996

Family Burmaeshnidae fam. nov.

Type species. Burmaeshna azari gen. et sp. nov.

Diagnosis. Wing venation only. Discoidal triangles very elongate; well-defined Mspl parallel to MA; two oblique veins "O" between RP2 and IR2; very elongate anal area with an anal loop distinctly longer than wide; presence of three primary antenodal crossveins Ax1, 'Ax2' and 'Ax3' in hindwing, with arculus situated between 'Ax2' and 'Ax3', while only two primary antenodals Ax1 and Ax2 in forewing. 
Genus Burmaeshna gen. nov.

Type species. Burmaeshna azari sp. nov.

Diagnosis. As for the family. Subdiscoidal spaces and hypertriangles free; reduced number of antenodal crossveins; two rows of cells in cubito-anal area of hind wing.

Burmaeshna azari sp. nov.

(Figs 1-2)

Holotype. NIGP165259 (incomplete fore- and hindwing), deposited at the Nanjing institute of Geology and Palaeontology.

Locality and Horizon. Hukawng Valley, Kachin Province, Myanmar; lowermost Cenomanian, Upper Cretaceous.

Diagnosis. As for genus. Discoidal triangles divided into three smaller cells.

Description. Basal third of a forewing, hyaline, $20.6 \mathrm{~mm}$ long, width unknown due to wrapping of the wing; distance from base to arculus ca. $3.8 \mathrm{~mm}$; from arculus to base of RP3/4 $7.7 \mathrm{~mm}$; nodus not preserved; four antenodal crossveins of primary type, viz. with a triangular membrane between $\mathrm{C}, \mathrm{ScP}$ and radius, $\mathrm{Ax} 0$ at extreme base of wing; distance from wing base to Ax1 ca. 3.0 mm, between Ax1 and 'Ax2' $1.4 \mathrm{~mm}$, between 'Ax2' and 'Ax3' 1.7 $\mathrm{mm}$; seven to nine preserved secondary antenodals crossveins; arculus situated midway between 'Ax2' and 'Ax3'; anterior part of arculus curved, RP and MA separated in angle of arculus where posterior part of arculus touches anterior part; hypertriangle $4.4 \mathrm{~mm}$ long, free; discoidal triangle $0.8 \mathrm{~mm}$ distal of arculus, divided into three smaller cells, very elongate and rather narrow, with anterior side $3.4 \mathrm{~mm}$ long, and MAb $3.4 \mathrm{~mm}$ long, sigmoidal; postdiscoidal area with two rows of cells just after discoidal triangle and three more distally; a distinct convex trigonal planate, short and zigzagged; only basal part of a well-defined Mspl 
present, well-defined with one row of cells between it and MAa; base of Mspl four cells distal of discoidal triangle; basal part of area between RA and RP with four crossveins basal of RP3/4, and two distal of base of RP3/4 and basal of subnodus; area between RP and MA with three crossveins basal of $\mathrm{RP} 3 / 4$; $\mathrm{Bq}$ space very long, but only one $\mathrm{Bq}$ crossvein; median area free; submedian area crossed by curved $\mathrm{CuP}$, situated below Ax1; subdiscoidal space free; one row of cells between MP and $\mathrm{CuA}$; two rows of cells in a narrow anal area; two rows of cells in area below $\mathrm{CuA}$; $\mathrm{CuA}$ without well-defined posterior branches.

Basal half of a hind wing, hyaline, fragment $20.6 \mathrm{~mm}$ long, wing $7.7 \mathrm{~mm}$ wide; very briefly petiolated, with stem of anal vein $0.9 \mathrm{~mm}$ long; distance from base to arculus $6.6 \mathrm{~mm}$; from arculus to nodus $8.7 \mathrm{~mm}$; from arculus to base of RP3/4 $6.3 \mathrm{~mm}$; four antenodal crossveins of primary type, viz. with a triangular membrane between $\mathrm{C}, \mathrm{ScP}$ and radius, $\mathrm{Ax} 0$ at extreme base of wing, Ax1 $3.6 \mathrm{~mm}$ distally, 'Ax2' $2.4 \mathrm{~mm}$ distally and a supplementary one 'Ax3' 1.7 mm distally, weaker than others and with a weaker membrane between C, ScP and RA; four secondary antenodal crossveins of first row not well aligned with the three crossveins of second row, distal of most distal primary antenodal; three postnodal crossveins preserved not well aligned with postsubnodal crossveins; one row of cells between RP1 and RP2; arculus $0.4 \mathrm{~mm}$ distal of $\mathrm{Ax} 2$; $\mathrm{RP}$ and $\mathrm{MA}$ separated in angle of arculus where posterior part of arculus touches curved anterior part; hypertriangle $3.9 \mathrm{~mm}$ long, free; discoidal triangle 0.7 mm distal of arculus, divided into three smaller cells, very elongate and rather narrow, with basal side $0.7 \mathrm{~mm}$ long, anterior side $2.9 \mathrm{~mm}$ long, and MAb $2.3 \mathrm{~mm}$ long, sigmoidal; postdiscoidal area with two rows of cells just after discoidal triangle, distally broadened with probably nine rows of cells along posterior wing margin; a distinct convex trigonal planate, short and zigzagged; only basal part of a well-defined Mspl present, well-defined with one row of cells between it and MAa; base of Mspl two cells distal of discoidal triangle; no pseudo-ScP distal of nodus; basal part of area between RA and RP with only one crossvein 
basal of RP3/4, and three distal of base of RP3/4 and basal of subnodus; area between RP and MA with one crossvein basal of RP3/4; two oblique veins "O", one cell distal of base of RP2 and one cell distally; one row of cells between IR2 and RP3/4 at least till two cells distal of subnodus; base of RP2 aligned with subnodus; base of Rspl clearly visible, with one row of cells between it and IR2; one row of cells between MP and CuAa; median area free; submedian area crossed by curved $\mathrm{CuP}$, situated between $\mathrm{Ax} 1$ and $\mathrm{Ax} 2$, closer to $\mathrm{Ax} 2$; subdiscoidal space free; no anal triangle and no anal angle (female specimen); postero-basal wing margin (AP) nearly straight; anal area very long but not very broad, $8.2 \mathrm{~mm}$ long, 3.4 mm wide, with two to three rows of very large cells between AA and AP basal of anal loop and no clear posterior branches of AA; anal loop two cells broad, much more elongate than broad, $3.4 \mathrm{~mm}$ long, $1.6 \mathrm{~mm}$ wide, hexagonal, posteriorly closed, divided into five cells; $\mathrm{CuAb}$ well-defined; cubito-anal area rather narrow, with three rows of cells between $\mathrm{CuAa}$ and posterior wing margin; $\mathrm{CuAa}$ with five posterior branches.

Discussion. Burmaeshna gen. nov. can be attributed to the Neoaeshnida Bechly, 1996 (Gomphaeschnidae + Aeshnodea) due to very elongate discoidal triangles, presence of only one row of cells between RP1 and RP2, well-defined Mspl and Rspl, parallel to MA and IR2, both pairs of wings with a strong convex secondary longitudinal vein (trigonal planate) in postdiscoidal area; in both pairs of wings MP and CuA closely parallel with only one row of cells between them up to wing margin (Bechly, 2016). Nevertheless, Burmaeshna has retained the two oblique veins "O" between RP2 and IR2, reduced for the Neoashnida. Burmaeshna shares with the Late Cretaceous family Enigmaeshnidae Nel et al., 2008 the very elongate anal area with an anal loop distinctly longer than wide (putative synapomorphies). The same character is possibly present in the Lower Cretaceous Anomalaeschna Bechly et al., 2001. Burmaeshna differs from Enigmaeshna Nel et al., 2008 in the free subdiscoidal space and hypertriangle, and the greatly reduced number of cells in all the areas and reduced number of 
antenodal crossveins (Nel et al., 2008). Burmaeshna differs from Anomalaeschna in the crossed discoidal triangle, and the position of the anal loop that is distal of the arculus level in Anomalaeschna. Therefore we consider that Burmaeshna represents a new family.

Burmaeshna has a unique character among the Aeshnoptera, viz. presence of three primary antenodal crossveins $\mathrm{Ax} 1$, 'Ax2' and 'Ax3', with arculus situated between 'Ax2' and 'Ax3', while in other Aeshnoptera, the arculus is situated between Ax1 and Ax2. Only Cymatophlebia purbeckensis Bechly et al., 2001 has three primary antenodals but its arculus is not between $\mathrm{Ax} 2$ and $\mathrm{Ax} 3$, but between $\mathrm{Ax} 1$ and Ax2 as in other Aeshnoptera (Bechly et al., 2001). Situations similar to what happen for Burmaeshna occur in some 'libelluloids' Synthemistidae (Fraser, 1952), in which a secondary antenodal crossvein between the true Ax1 and Ax2 has been reinforced to become identical to the true primary antenodals.

With the discovery of the Burmaeshnidae, there is no less than four aeshnopteran families currently recorded in the Late Cretaceous, two of them becoming extinct before the Paleocene, maybe during the K-T crisis or before. No fossil odonatan is known in the Maastrichian.

\section{Acknowledgements}

Dr. Huang has been supported by the Strategic Priority Research Program (B) of Chinese Academy of Sciences (CAS) (XDB18000000), and the National Natural Science Foundation of China (41688103, 91514302).

\section{References}

1. Bechly, G. (1996) Morphologische Untersuchungen am Flügelgeäder der rezenten Libellen und deren Stammgruppenvertreter (Insecta; Pterygota; Odonata), unter 
besonderer Berücksichtigung der Phylogenetischen Systematik und des Grundplanes der Odonata. Petalura, Böblingen, Special Volume 2, 402 pp.

2. Bechly, G. (2016) Phylogenetic systematics of Odonata. - homepage on the Internet: https://dl.dropboxusercontent.com/u/13756162/Website/odonata/system.htm

3. Bechly, G., Nel, A., Martínez-Delclòs, X., Jarzembowski, E.A., Coram, R., Martill, D., Fleck, G., Escuillié, F., Wisshak, M.M., Maisch, M. (2001) A revision and phylogenetic study of Mesozoic Aeshnoptera, with description of several new families, genera and species (Insecta: Odonata: Anisoptera). Neue Paläontologische Abhandlungen, 4, 1-219.

4. Cockerell, T.D.A. (1913) Two fossil insects from Florissant with a discussion of the venation of the aeschnine dragon-flies. Proceedings of the United States National Museum, 45, 577-583.

5. Cruickshank, R.D., Ko, K. (2003) Geology of an amber locality in the Hukaung Valley, northern Myanmar. Journal of Asian Earth Sciences, 21, 441-455.

6. Dutta, S., Mallick, M., Kumar, K., Mann, U., Greewood, P.F. (2011) Terpenoid composition and botanical affinity of Cretaceous resins from India and Myanmar. International Journal of Coal Geology, 85, 49-55.

7. Fabricius, J.C. (1793) Entomologia systematica emendata et aucta, secundum classes, ordines, genera, species, adjectis synonymis, locis, observationibus, descriptionibus. C.G. Proft, Hafniae [= Copenhagen], 3, 1-487 and 1-349.

8. Fraser, F.C. (1952) A further note on the remarkable characters of the Syntheminae (Corduliidae). Entomologists' Monthly Magazine, 88, 158-159.

9. Grimaldi, D. (2016) Diverse orthorrhaphan flies (Insecta: Diptera: Brachycera) in amber from the Cretaceous of Myanmar: Brachycera in Cretaceous amber, Part VII. Bulletin of the American Museum of Natural History, 408, 1-131. 
10. Grimaldi, D., Engel, M.S., Nascimbene, P. (2002) Fossiliferous Cretaceous amber from Myanmar (Burma): its rediscovery, biotic diversity, and paleontological significance. American Museum Novitates, 3361, 1-72.

11. Grimaldi, D., Ross, A.S. (in press). Extraordinary Lagerstaetten in amber, with particular reference to the Cretaceous of Burma. In: Fraser, N.C., Sues, H.-D. (eds). Terrestrial Conservation Lagerstätten: Windows into the Evolution of Life on Land. Dunedin Press, Edinburgh, UK.

12. Nel, A., Martinez-Delclos, X., Paicheler, J.-C., Henrotay, M. (1993) Les 'Anisozygoptera' fossiles. Phylogénie et classification (Odonata). Martinia, Numéro Hors Série 3, 1-311.

13. Nel, A., Martínez-Delclòs, X., Escuillié, F., Brisac, P. (1994) Les Aeshnidae fossiles: Etat actuel des connaissances (Odonata, Anisoptera). Neues Jahrbuch für Geologie und Paläontologie, Abhandlungen, 194, 143-186.

14. Nel, A., Néraudeau, D., Perrichot, V., Girard, V., Gomez, B. (2008) A new dragonfly family in the Upper Cretaceous of France (Insecta: Odonata: Aeshnoptera). Acta Palaeontologica Polonica, 53, 165-168.

15. Poinar, G.O.Jr., Lambert, J.B., Wu, Y. (2007) Araucarian source of fossiliferous Burmese amber: spectroscopic and anatomical evidence. Journal of the Botanical Research Institute of Texas, 1, 449-455.

16. Riek, E.F., Kukalová-Peck, J. (1984) A new interpretation of dragonfly wing venation based upon Early Carboniferous fossils from Argentina (Insecta: Odonatoidea) and basic characters states in pterygote wings. Canadian Journal of Zoology, 62, 11501166. 
17. Ross, A., Mellish, C., York, P., Crighton, B. (2010) Burmese amber. In: Penney, D. (Ed.), Biodiversity of fossils in amber from the major world deposits. Siri Scientific Press, Manchester, 208-235.

18. Selys-Longchamps, E. de, Hagen, H. (1954) Synopsis des Gomphines. Bulletin de l'Académie Royales des sciences et belles-lettres de Bruxelles, 21, 23-114.

19. Shi, G.-H., Grimaldi, D.A., Harlow, G.E., Wang, J., Yang, M.-C., Lei, W.-Y., Li, Q., Li, X.-H. (2012) Age constraints on Burmese amber based on U-Pb dating of zircons. Cretaceous Research, 37, 155-163.

20. Tappert, R., McKellar, R.C., Wolfe, A.P., Tappert, M.C., Ortega-Blanco, J., Muehlenbachs, K. (2013) Stable carbon isotopes of C3 plant resins and ambers record changes in atmospheric oxygen since the Triassic. Geochimica et Cosmochimica Acta, $121,240-262$.

21. Tillyard, R.J., Fraser, F.C. (1940) A reclassification of the order Odonata based on some new interpretations of the venation of the dragonfly wing. Part 3. The Australian Zoologist, 9, 359-396.

22. Zheng, Daran, Jarzembowski, E.A., Chang, Su-Chin, Wang, Bo (2016) A new true dragonfly (Odonata, Anisoptera, Gomphaeschnaoidini) from mid-Cretaceous Burmese amber. Proceedings of the Geologists' Association, 127, 629-632.

23. Zheng, Daran, Chang, Su-Chin, Jarzembowski, E.A., Wang, Bo (2017) The first aeshnoid dragonfly (Odonata: Anisoptera: Telephlebiidae) from mid-Cretaceous Burmese amber. Cretaceous Research, ????

24. Zherikhin, V.V., Ross, A.J. (2000) A review of the history, geology and age of Burmese amber (Burmite). Bulletin of the Natural History Museum, Geological Series, $56,3-10$. 
Fig. 1. Burmaeshna azari gen. et sp. nov., holotype NIGP165259, hindwing, photographs. A, base from below; $\mathrm{B}$, base from above; $\mathrm{C}$, distal part from above; $\mathrm{D}$, nodal region (scale bars represent $3 \mathrm{~mm}$ ).

Fig. 2. Burmaeshna azari gen. et sp. nov., holotype NIGP165259. A-B, forewing, photographs. A, base; $\mathrm{B}$, nodal region (scale bars represent $3 \mathrm{~mm}$ ); $\mathrm{C}$, reconstruction of hindwing (scale bar represents $4 \mathrm{~mm}$ ). 


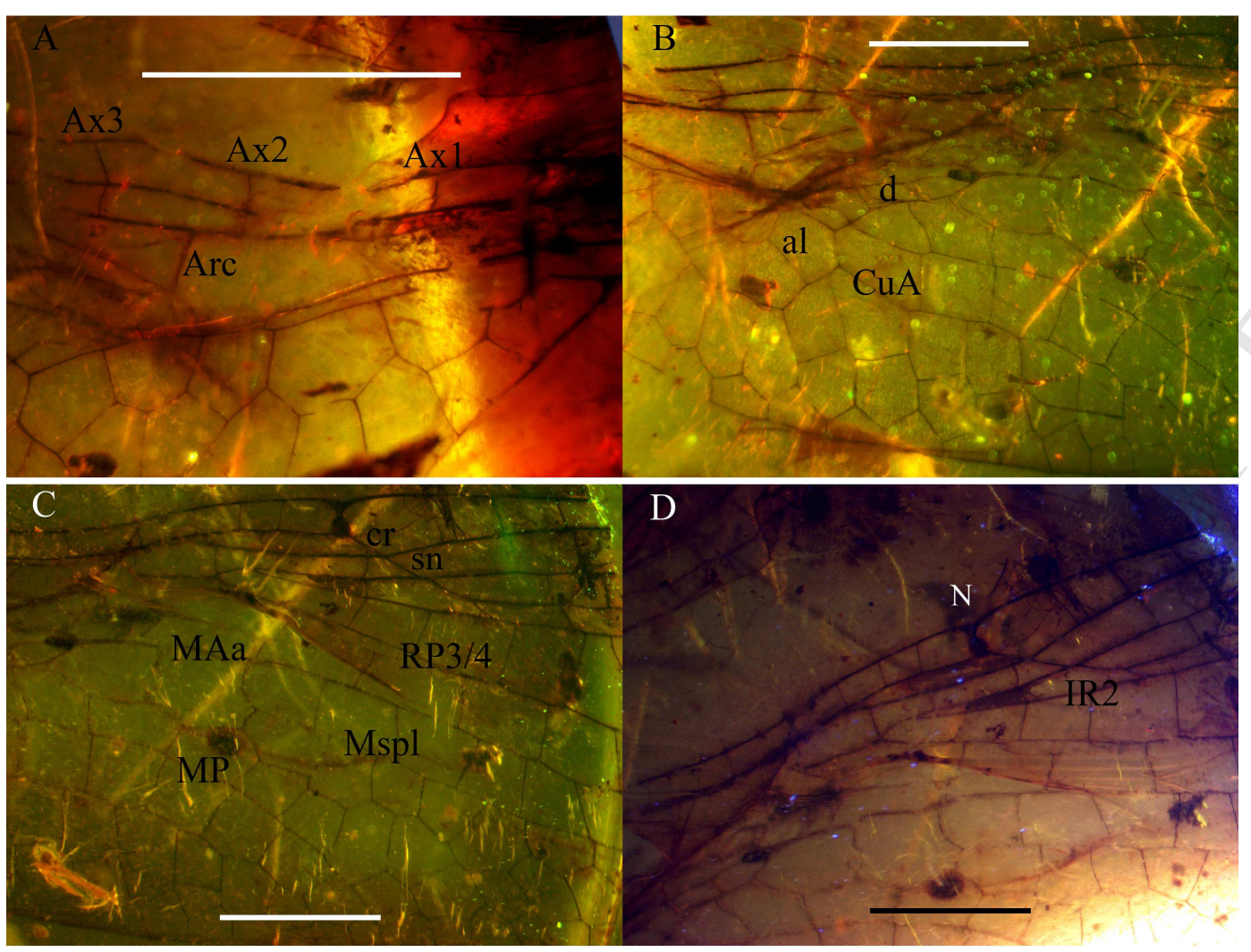



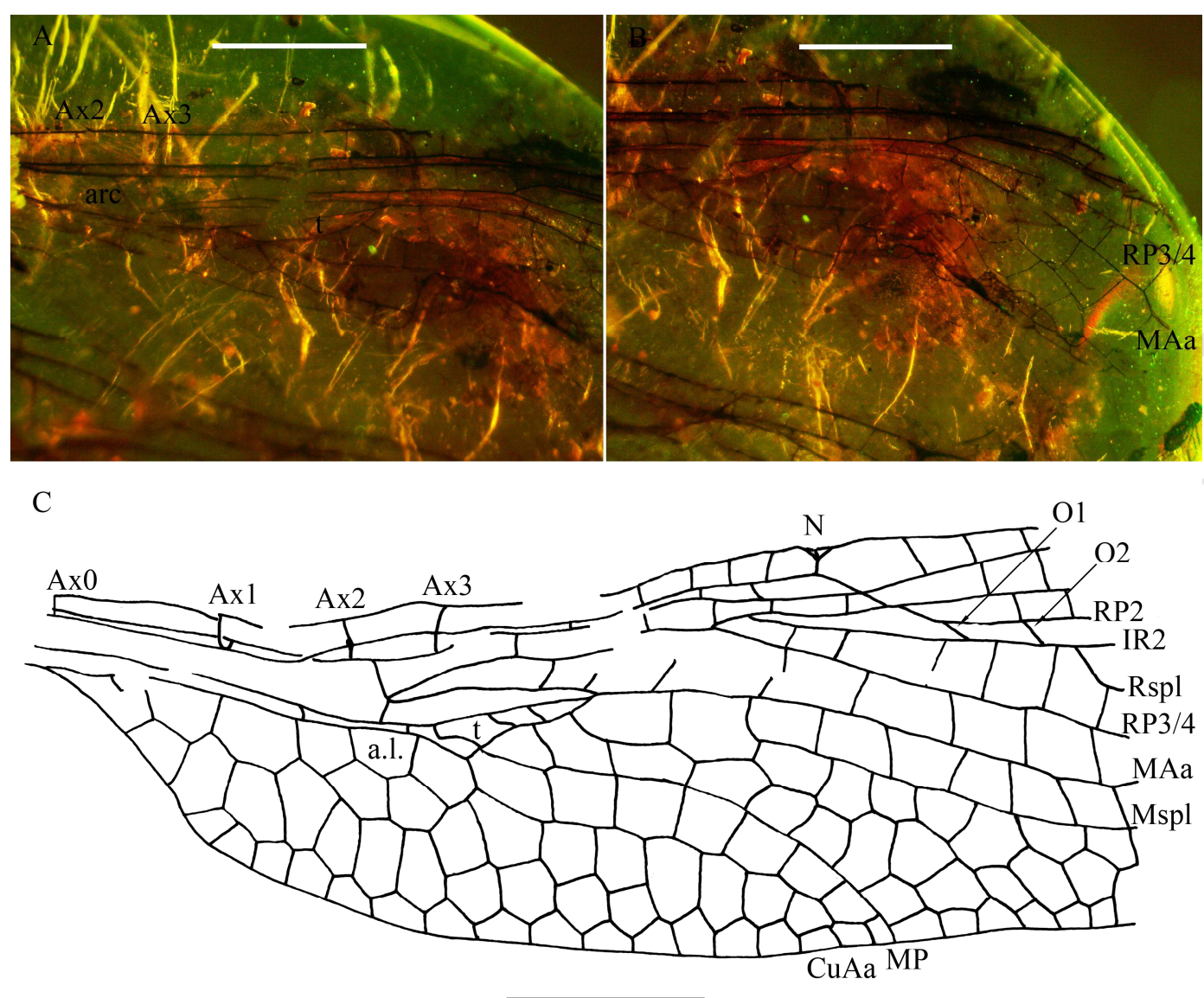